\title{
P70S6K/Akt Inhibitor MSC2363318A
}

National Cancer Institute

\section{Source}

National Cancer Institute. p7056K/Akt Inhibitor MSC2363318A. NCI Thesaurus. Code

C112004.

An orally available inhibitor of the serine/threonine protein kinases ribosomal protein S6 Kinase (p70S6K) and Akt (protein kinase B), with potential antineoplastic activity. Upon administration, p70S6K/Akt inhibitor MSC2363318A binds to and inhibits the activity of p70S6K and Akt. This prevents the activation of the PI3K/Akt/p70S6K signaling pathway and inhibits tumor cell proliferation in cancer cells that have an overactivated $\mathrm{PI3K} /$ Akt/p70S6K signaling pathway. Constitutive activation and dysregulated signaling of the PI3K/Akt/p70S6K pathway are frequently associated with tumorigenesis of many tumor types; targeting multiple kinases in this pathway is more efficacious than targeting a single kinase. 